\title{
Di Bawah Bayang-Bayang Syariat: Islam, Islamisme dan Demokrasi di Kota Surakarta
}

\section{Muhammad Adnan}

Departemen Politik dan Pemerintahan, Universitas Diponegoro

\begin{abstract}
Abstrak:
Kajian ini dikhususkan pada dimamika relasi Islam, Islamisme dan demokrasi di Surakarta. Kajian dilaksanakan dengan melakukan wawancara terhadap beberapa aktivis Islam dan aktivis Islam politik. Analisis dilakukan dengan menggunakan teori sikap dan teori identitas untuk menjajagi sejauhmana sikap mereka terhadap praktik demokrasi, yaitu pemilihan kepala daerah dan pemilihan anggota legislatif. Seberapa kuat peran identitas ke-Islam-an mereka menyikapi pemilihan tersebut. Hasil kajian menunjukkan, aktivis Islam non-politik terbagi dalam dua kelompok. Satu kelompok dapat menerima demokrasi secara utuh tanpa dikaitkan dengan persoalan syariat, bahkan demokrasi diangggap sudah sesuai dengan syariat. Sebaliknya, kelompok kedua menerima demokrasi tetapi menekankan pentingnya memiliki pemimpin Islam. Kalaupun yang terpilih non Muslim, mereka bisa menerima tetapi dengan kondisi terpaksa. Sikap ini juga berlaku untuk pemilihan anggota legislatif. Kelompok Islam politik juga terbagi menjadi dua sikap yaitu kelompok Islamis-idealis dan Islamis-realis. Kelompok yang idealis total menolak praktik demokrasi termasuk pemimpin non-Islam. Kelompok realis, masih bisa menerima demokrasi tetapi haram memilih pemimpin non Islam. Praktik demokrasi di Surakarta untuk waktu yang tidak bisa ditentukan akan senantiasa dibayang-bayangi tiga fenomema. Pertama, dominasi sikap aktivis Islam yang menggunakan standar syariat menurut interpretasi mereka dalam memilih pemimpin politik. Kedua, dominasi sikap aktivis Islam politik yang lebih total dalam menggunakan standar syariat yaitu menetapkan keharaman dalam memilih pemimpin non Islam. Ketiga, sikap Islamis-idealis yang total menolak sistem demokrasi, meskipun pemimpin yang terpilih beragama Islam.
\end{abstract}

Keywords:

Islam; Islamisme; demokrasi; syariat

\section{Pendahuluan}

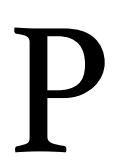

erdebatan tentang relasi agama dan negara hingga saat ini belumlah selesai bahkan semakin menarik untuk dipelajari, Perdebatan telah bergeser dan berfokus tidak lagi berhenti hanya membahas relasi agama dan negara yang masih bersifat abstrak, tetapi secara lebih spesifik dan konkrit mempersoalkan relasi agama dan politik, agama dan demokrasi, hingga pada agama 
dan pemilihan (umum). Pergeseran ini dipicu dan terutama dipengaruhi oleh perkembangan pemikiran di kalangan sarjana Barat dan Islam. Pertama, pemikiran yang meyakini perlunya keterpisahan agama dan negara (sekularisme) tetapi tidak lagi mengabaikan peran agama. Kedua, pemikiran yang mengharuskan integrasi agama dan negara (teokrasi) tetapi bisa menerima nilai-nilai sekuralisme. Ketiga, pemikiran yang memisahkan agama dan negara tetapi tidak dalam konteks hubungan agamapolitik, dan tidak anti pada nilai-nilai demokrasi yang dikembangkan oleh paham sekularisme. Dinamika diskursus relasi agama dan negara juga diperkaya dan menjadi aktraktif oleh munculnya paham dan aliran politik dalam Islam yang sangat kompleks dan konfliktual.

Islam, diyakini sebagai agama yang memiliki konsep dalam mengatur dan menata kehidupan sosial, ekonomi, hukum, dan politik untuk umat menusia. Akan tetapi, karena pemikiran tentang relasai agama dan negara dalam Islam tidak tunggal, maka muncullah variasi dan kombinasi pemikiran yang pada batas tertentu bisa saja merupakan amalgamasi dari pemikiran atau setidaknya rapproachment dari paham sekularisme dan teokrasi.

Dinamika dan perkembangan pemikiran politik Islam ini dalam perspektif teoritis menimbulkan tiga pendekatan. Pertama, agama dan negara terpisah (separatedi), yang disebut dengan sekularisme. Pemikiran separasi agama dan negara ini ditolak mentah-mentah oleh Islam politik, karena hal itu bertolak belakang dengan misi Islam itu sendiri, yaitu keselamatan umat manusia, yang membutuhkan kepemimpinan dan negara.

Kedua, agama dan negara terintegrasi (integrated), disebut dengan teokrasi/negara agama. Dalam sistem ini, nilai-nilai agama tidak hanya sekedar mewarnai, akan tetapi menjadi referensi kebijakan dan sumber hukum utama bagi negara, melahirkan paham Islamisme, Revivalisme, Fundamentalisme dengan keinginan kuat mendirikan Daulah Islamiyyah/the Islamic State/Khilafah. Meskipun demikian, konsep intergrasi ini juga tidak bersifat tunggal. Bagi kelompok Islamisidealis, integrasi itu bersifat mutlak dan bahkan berlaku secara internasional, di mana ada satu kekuatan Islam global/supra nasional yang mengatur kekuatan-kekuatan Islam pada level negara/nasional. Kelompok ini cenderung anti demokrasi dan anti nation-state. Sedangkan bagi kelompok Islamis-realis, Islam boleh saja bersinergi dengan kekuatan sekuler selama tujuan Islamisme belum tercapai.

Ketiga, agama dan negara separated, tapi agama, khususnya Islam dan Politik bersifat interaktif. Pemikiran ketiga ini merupakan jalan tengah yang dianut oleh kelompok Islam moderat. Ketidakpuasan terhadap praktek sekularisme di satu sisi dan ketidakinginan mendirikan negara agama memunculkan pendekatan alternatif sebagai midway approach, yaitu agama dan negara terpisah akan tetapi agama (baca: Islam) dan politik interaktif (An-Naim, 2008). Landasan pemikiran kelompok ini 
adalah bahwa faktanya, Islam tidak mengatur bentuk negara tertentu dan atau mewajibkan untuk mendirikan negara Islam sebagaimana keyainan the Islamists.

Namun demikian, meskipun Islam dan negara terpisah, tetapi nilai-nilai Islam dalam mewujudkan tatanan masyarakat yang adil, aman, sejahtera dan seterusnya haruslah diperjuangkan melalui gerakan dan kegiatan politik di dalam sebuah negara, apapun bentuk dan sistem yang diperlakukan di negara tersebut. Tidak hanya sekedar jalan tengah, pendepatan dan gagasan ini lebih tepat disebut sebagai post Islamism, yang melahirkan gagasan antara lain Civil Islam dan post ideology-Islam. Post ideology-Islam, kata Karabela \& Brenna (2015) lebih menitik beratkan pada isu-isu etika, keadilan sosial dan pluralisme daripada memikirkan bentuk negara/pemerintahan. Berbeda dengan Political Islam, civil Islam menurut Hefner lebih fokus pada pembangunan spiritual individu Muslim, penguatan civil society, kebebasan bergama, etika, keadilan sosial dan rule of law. Gagasan ini tidak mentrasformasikan Islam ke dalam idoelogi politik dan tidak bersifat state-centric (Hefner, 20I2).

Secara kooinsidensi, paham Sekularisme juga mengalami perkembangan yang cukup signifikan, Perkembangan ini mungkin tidak pernah terbayangkan oleh bapak sekularisme, John Locke. Dalam implementasinya, paham sekularisme ini diterapkan secara berbeda di negara-negara yang menjadi rujukan sekularisme. Perancis misalnya, menerapkan positive secularism (McClay, 2002: 63), assertive secularism (Kuru, 2009: II). Dengan positive atau assertive secularism, negara memainkan peran yang tegas, mengeluarkan agama dari ruang publik dan membatasi agama hanya pada domain privat. Penulis menyebut ini sebagai absolute secularism. Sebaliknya, AS menerapkan passive secularism atau negative secularism (Kuru, 2009: II). Dengan sekularisme pasif atau negatif, negara memainkan peran pasif dengan mengijinkan agama tampak di ruang publik. Kebijakan-kebijakan negara secara konstan mengakomodasi agama di ruang publik. Penulis menyebut sekularisme jenis ini sebagai limited secularism. Meskipun demikian, baik sekularisme yang positif maupun negatif, keduanya merupakan negara sekuler, nation-state, dan menganut sistem demokrasi,

Jika praktik sekularisme di Barat saja tidak tunggal, maka implementasi sekularisme di banyak negara yang mayoritas penduduknya beragama Islam memperlihatkan tingkat keragaman yang tinggi, sehingga terkadang menimbulkan keraguan apakah sistem campuran itu applicable atau tidak. Dilandasi pemikiran bahwa pengalaman sekularisme Barat tidaklah sama dengan sejarah tumbuhnya sekularisme di negara-negara mayoritas berpenduduk Islam, maka ide tentang post secularism bertemu dengan ide post Islamism. Dalam bahasa Hashemi, (Ali dalam Akbar, 20I6) sekularisme Barat merupakan proses button up, hasil debat civil society, sedangkan sekularisme dalam masyarakat Muslim sebagian besar merupakan proses top down yang tidak memiliki basis dukungan civil society. Dengan mengadopsi 
sekularisme tanpa meninggalkan nilai-nilai religi, maka muncullah gagasa tentang religious secularity dan democratic religious society. Jika Islamisme adalah sebuah proyek politik yang berusaha untuk memberi energi dan mengorganisir Muslim untuk berjuang melawan apa yang dipersepsikan sebagai sistem yang didominasi Barat, maka post Islamism mencari titik temu antara nilai Islam dengan nilai-nilai Barat.

Di satu sisi, Islamisme terpaksa harus mengakui bahwa mereka berada di bawah sistem global yang dominan sekuler, sehingga mau tidak mau harus melakukan beberapa penyesuaian dan adaptasi. Di sisi yang lain, Sekulerisme harus mengakui tentang peran agama yang tidak bisa diabaikan, bahkan yang semula diprediksi akan lenyap justru perannya di abad ke 2I ini semakin diperhitungkan. Sebagai implikasinya, diskursus relasi agama dan negara bergeser ke arah yang lebih praksis yaitu pada relasi antara agama dan demokrasi, lebih khusus lagi Islam dan demokrasi.

Meskipun gagasan ideologi sekularisme dan Islamisme telah mengalami perkembangn dan perubahan yang berarti, dengan dialogisasi dan interaksi keduanya sehingga menghasilkan kombinasi saling mengisi, akan tetapi keinginan untuk mempertahankan dan memperjuangkan Islamisme tidaklah pudar. Secara teoritis, hal itu didorong oleh tiga trigger utama yaitu, spiritualisme, psikologi dan power. Spirit spiritual untuk menjadi Muslim yang melaksanakan ajaran sesuai dengan al-Qur'an dan as-Sunnah, aspek psikologi karena merasa tertekan oleh dominasi Barat yang sekuler dan dianggap tidak adil, dan proyek besar untuk mencapai kekuasaan melalui perjuangan "agama".

Di Indonesia, kebangkitan untuk memperjuangkan Islamisme mendapatkan momentumnya ketika gelombang reformasi politik menyebabkan runtuhnya kekuasaan Orde Baru. Kekuatan Orde Baru yang represif mampu dan berhasil menahan dan menekan gerakan Islamisme yang bertujuan mendirikan negara Islam, seperti gerakan Darul Islam (DI) dan Negara Islam Indonesia (NII). Ketika bendungan Orde Baru jebol, maka air bah Islamisme melanda Indonesia, tidak hanya gerakan yang bersifat lokal seperti DI-NII, Majlis Mujahidin Indonesia (MMI) dan lain-lain, akan tetapi juga gerakan Islamisme internasional seperti Hizbut Tahrir (HT), Ikhwanul Muslimin, Al Qaeda, dan lain-lain.

Munculnya aksi teror yang mematikan dan serangkaian kekerasan politik atas nama agama di berbagai wilayah khususnya kota-kota strategis seperti Bali , Jakarta dan Surakarta, adalah ekpressi dari keinginan mendirikan negara Islam yang menjadi cita-cita gerakan Islamisme.

Paralel dengan kebangkitan Islamisme di era reformasi, kebangkitan demokrasi substantif juga mendapatkan momentumnya. Dua paradigma politik yang berseberangan ini; Islamisme dan Demokrasi, berjalan sama kencanganya dalam perebutan mencapai garis finish. Islamisme melakukan gerakan dan tuntutan dari yang paling minimal seperti menghidupkan kembali piagam Jakarta, pemberlakuan 
syariat Islam, hingga pembentukan negara Islam. Demokrasi melakukan konsolidasi dengan melakukan koreksi atas chekcs and balances yang selama ini kabur dan tidak berfungsi, hingga menata ulang proses suksesi kepemimpinan politik di tingkat nasional, regional dan lokal dalam satu tarikan nafas yaitu pemilihan umum langsung oleh rakyat.

Secara normatif, Di satu sisi sulit membayangkan Islamis yang anti demokrasi bersedia mengikuti proses demokrasi seperti pemilihan umum. Di sisi lain, sulit mengharapkan praktik demokrasi modern liberal dapat diikuti oleh kekuatankekuatan Islamis.

Namun demikian, situasi antagonis yang tampaknya tidak mungkin dipertemukan itu menjadi anomali ketika kita melihat praktik demokrasi politik di kota Surakarta. Di kota ini, Pemilihan Kepala Daerah secara langsung dapat berjalan dengan baik, rutin, tanpa kekerasan dan bahkan dengan tingkat pertisipasi politik pemilih yang tinggi. Pada saat yang sama, di kota ini, aktivitas dan gerakan Islamisme tumbuh dengan pesat dan menjadi ukuran kekuatan Islamisme secara nasional.

Sejak tahun 2005 hingga tahun 2020, seiring dengan menguatnya Islamisme di kota Surakarta, prosentase pemilih relatif tinggi meskipun fluktuatif. Pada Pemilukada 2005, terdapat $76 \%$ partisipasi politik. Tahun 2010 turun cukup signifikan menjadi $7 \mathrm{I} \%$. Tahun 2015 naik sedikit menjadi 74\%. Tahun 2020 kembali turun dengan partisipasi 70.52\% (KPU Kota Surakarta). ${ }^{\mathrm{I}}$

Data di atas adalah sebuah anomali, pada saat demokrasi dianggap sebagai ciptaan manusia, kafir, sistem thoghut dan sederet label negatif lainnya, yang diberikan oleh kelompok Islamis, tetapi prosentase suara pemilih cukup tinggi bahkan dibandingkan dengan daerah lain yang gerakan Islamimsme-nya rendah, seperti kota Semarang. Pada periode yang sama partisipasi pemilih di Kota Semarang adalah: tahun 2005 sebesar 66\%, tahun 2020, 60,02\%, tahun 2015, 65,48\%, dan tahun 2020 sebesar $68,62 \% .^{2}$

Menjadi pertanyaan menarik untuk kaji, bagimanakah pandangan Islamis di kota Surakarta terhadap demokrasi, khususnya pemilihan kepala daerah? Apakah mereka menggunukan hak pilihnya? Apakah tingkat partisipasi pemilih yang tinggi di Pemilukada Surakarta disebabkan oleh kebersediaan mereka menggunakan hak pilihnya? Demikian pula dengan pemilihan anggota DPRD, apakah mereka menggunakan hak pilihnya? Bagaimana sikap mereka terhadap calon yang non Muslim baik untuk jabatan eksekutif maupun keanggotaan legislatif.

Selain dari fakta tingginya tingkat partisipasi pemilih, Surakarta mendapat julukan kota sumbu pendek, artinya mudah sekali terjadi kebakaran sosial dan politik, maskipun hanya dipicu oleh peristiwa kecil. Peristiwa yang menjadi pemicu pun tidak hanya lokal atau nasional, akan tetapi juga peristiwa yang terjadi di negara lain, yaitu

\footnotetext{
${ }^{1}$ https://kota-surakarta.kpu.go.id (data diolah)

2 https://kpu-semarangkota.go.id
} 
peristiwa yang dianggap merugikan Islam atau umat Islam, peristiwa politik dan keagamaan yang terjadi di kota ini selalu menjadi perhatian nasional. Secara lebih spesifik, pilihan terhadap kota ini adalah, Pertama, kota ini menjadi pusat dari gerakan Islam puritan-rigid tetapi sekaligus pusat dari Islam sinkretis. Kedua, kota ini dikenal sebagai markas dan barometer gerakan fundamentalis, the Islamis bahkan Jihadis. Ketiga, kota ini menjadi ladang subur bagi gerakan intoleransi keagamaan, baik intern agama maupun antar agama. Keempat, tidak bisa dipungkiri bahwa kota Surakatarta adalah centrum Islam politik.

\section{Islam, Islamisme dan Demokrasi: Perdebatan Konsep yang Tidak Kunjung Selesai}

Perebutan konsep Islam dan demokrasi lebih disebabkan oleh kesalahpahaman di antara pendukung dua konsep tersebut, yaitu pandangan yang menolak demokrasi dan pandangan yang menolak Islam. Di satu sisi, pemikiran yang menolak praktik demokrasi karena dianggap itu adalah buatan manusia yang tidak sempurna dan cacat lahir. Islam adalah solusi atas semua sistem buatan manusia yang rapuh. Demokrasi yang meletakkan kedaulatan di tangan rakyat sebagai kekuasaan tertinggi, tidak bisa dibenarkan karena kekuasaan tertinggi adalah milik Tuhan melalui wahyu dan firman-Nya. Demokrasi yang memberikan kepada rakyat suara terbanyak untuk menetapkan keputusan, bertentangan dengan misi syariat bahwa ukuran hukum bukanlah suara terbanyak tetapi syariat Islam.

Jika syariat memutuskan bahwa minuman keras itu haram, maka tidak ada keputusan manusia meskipun mayoritas yang dapat merubahnya menjadi halal. Pembelaaan maksimum seperti ini dilakukan oleh Maududi (1990), yang menolak mentah-mentah demokrasi karena didasarkan pada kedaulatan manusia. Maududi sempat menawarkan konsep theo-democracy untuk menutupi kelemahan konsep popular democracy, karena sebenarnya dia juga anti pada sistem kerajaan yang banyak dipraktikkan di negara-negara Arab.

Akan tetapi pada era sekarang, konsep theo-democracy Maududi ini tidak mudah untuk diterapkan karena ini didasarkan pada dominasi laki-laki, dan pilihannya pada sistem khilafah atau the IslamicState tidak berubah. Bagi kelompok anti demokrasi, demokrasi dianggap sesuatu yang haram. Esposito menggambarkan sikap kelompok ini terhadap demokrasi yang dianggap konsep asing, dan kedaulatan rakyat (popular soverign) adalah bertentangan dengan supremasi kekuasaan Tuhan (Espito \& Mogahed, 2007: 55).

Di sisi lain, pendapat yang dengan tegas menolak Islam dengan demokrasi tidak kalah kerasnya, bahkan menuduh Islam adalah sumber masalah bagi demokrasi. Dalam praktiknya, negara-negara mayoritas berpenduduk Islam adalah rezim yang otoriter, jauh dari nilai dan praktik demokrasi. Bukan hanya pemeluk Islam yang menjadi hambatan bagi tumbuh dan berkembangnya demokrasi, tetapi Islam itu 
sendiri sarat dengan nilai-nilai yang tidak sejalan dengan demokrasi. Nilai-nilai itu misalnya tidak adanya pembatasan kekuasaan yang diatur dalam syariat Islam sehingga potensi melahirkan kediktaroran. Padahal, pembatasan kekuasaan adalah esensi demokrasi modern yang tidak bisa ditawar.

Huntington adalah salah satu tokoh vocal yang menyuarakan tentang pertentangan Islam dan demokrasi yang tidak mungkin dipertemukan. Dalam tesisnya, dia mengatakan bahwa permasalahan yang dihadapi oleh Barat bukanlah fundamentalisme Islam, akan tetapi Islam itu sendiri masalah (Huntington \& Simamora, 1983: 217). Dengan menggunakan analisis statistik, Potrafke (2012) mendapatkan data bahwa mayoritas negara muslim memang kurang demokratis. Temuan ini memperkuat data empirik sebelumnya oleh Rowley \& Smith (2009) yang mengatakan bahwa warga di negara mayoritas Islam kurang mendapatkn kebebasan dibandingkan dengan negara yang minoritas Islam.

Potrafke (2012) bahkan lebih lanjut memotret bahwa Islam itu sendiri adalah agama yang secara intrinsik represif, kurang memberi tempat bagi kebebasan individu dan institusi demokrasi. Senada dengan pandangan Huntington dan kajian empiris Potrafke dan Rawley, Bernard Lewis berpendapat bahwa Islam hanya mengakomodir negara teokratis bukan demokrasi liberal (Huntington \& Simamora, 1983: 96). Dalam menggambarkan adanya musuh internal dan eksternal terhadap demokrasi, Todorov (2004: 4), menyebutkan bahwa fundamentalisme Islam sebagai ancaman eksternal dan musuh baru yang memerangi demokrasi. Schneier (2015: 233) menyebutkan bahwa Menjadi seorang Muslim tidak memiliki efek substantif yang berarti tentang sikap terhadap demokrasi.

Memperkuat pendapat-pendapat di atas, Fukuyama (2006: 29-30),setelah peristiwa II/9 menulis:

... Bukan kebetulan bahwa demokrasi liberal modern muncul pertama kali di Barat Kristen, karena universalisme hak demokratis dapat dilihat sebagai bentuk sekuler dari universalisme Kristen. . . Tetapi tampaknya ada sesuatu tentang Islam, atau setidaknya versi fundamentalis Islam yang telah dominan dalam beberapa tahun terakhir, yang membuat masyarakat Muslim terutama menolak modernitas.

Munculnya pandangan negatif terhadap Islam seperti ini tidak terlepas dari sudut pandang dalam memahami Islam politik, generalisasi Islam dan Islam politik atau fundamentalisme dan Jihadisme .

Di antara kedua kutub pemikiran yang ekstrim tersebut ada Islam mainstream yang moderat, yang meyakini bahwa nilai-nilai dalam Islam compatible dengan nilainilai demokrasi. Bahkan, Islam tidak hanya mampu mengisi kekosongan yang tidak bisa diisi oleh demokrasi, Islam memberi energi baru bagi demokrasi dalam praktiknya di negara-negara mayoritas memeluk Islam. Pembelaan terhadap Islam 
tanpa mempertentangkan demokrasi apalagi menafikannya dilakukan oleh beberapa penulis.

Esposito (2002) menjelaskan bahwa agama-agama pra modern, semuanya mendukung sistem monarkhi dan sistem sosial feudal. Setelah itu baru bergerak mengakomodasi norma-norma modern demokrasi. Bahkan agama Kristiani pun yang dianggap paling kompatibel dengan demokrasi, hingga hari ini pun masih ada sekte yang meyakini bahwa bahwa demokrasi bertentangan dengan Kristiani, karena tidak berlandaskan pada hukum dan kehendak Tuhan. Sekte kuno dalam Kristiani mendorong ketaatan pada penguasa meski otoriter selama mereka tidak ateis dan tidak membahayakan para pengikutnya. Demokrasi, bahkan dianggap sebagai penyebab semua masalah dunia (Bayat, 2005).

Semuanya pergeseran keyakinan ideologi itu melalui proses yang panjang sehingga demokrasi dapat lebih berkembang di negara-negara yang mayoritas beragama Kristen. Apabila hari ini mayoritas negara Islam atau yang berpenduduk Islam hanya satu dari empat negara yang demokratis, maka sebetulnya akar persoalannya bukan pada agama akan tetapi lebih pada persoaalan sosial politik. Jika beberapa negara di Timur Tengah dan Afrika Utara yang otoriter dan anti demokrasi, bukan karena penduduk mereka beragama Islam, tetapi lebih disebabkan kekhawatiran para pemimpin dan penguasa di sana yang tidak ingin kehilangan kekuasaan karena adanya pemilihan pemimpin secara rutin, terbuka melalui kontestasi dan kompetisi politik transparan.

Oleh karenanya, tidak mengherankan jika Raja Fahd Saudi mengatakan bahwa demokrasi tidak cocok untuk wilayah ini (Arab), atau pangeran Abdullah Yordania saat memberikan alasan keamanan (security) sehingga tidak mungkin melakukan suksesi terbuka (Esposito \& Mogahed, 2007). Secara empiris hari ini terbukti, beberapa negara mayoritas Islam yang dahulunya otoriter atau berdemokrasi hanya sebagai simbol dan alat legitimasi saja, saat ini mulai bergerak ke arah sistem yang lebih demokratis secara substantif. Sebut saja misalnya Turki, Indonesia, dan Bangladesh yang secara relatif berhasil melakukan suksesi. Aljazair, Maroko dan bahkan Yaman, pun berusaha melakukan eksperimen embrionik demokrasi yang atraktif.

Dalam menjelaskan masalah supremasi kekuasaan hukum tertinggi adalah milik Tuhan, maka kelompok penengah ini memberikan argumentasi sebagai berikut. Pertama, kedaulatan yang berada di tangan Tuhan itu telah didelegasikan kepada manusia sesuai dengan firmanNya (Quran, 2:30). Kedua, kedaulatan harus dipahami sebagai kedaulatan yang bersifat prinsip (de jure), dan kedaulatan yang faktual ( de facto). Baik dalam negara demokrasi maupun negara Islam, kadaulatan de facto adalah manusia. Meskipun dalam negara Islam Tuhan adalah lawgiver dan dalam demokrasi sumber hukum adalah human agents, tetapi manusia memiliki otoritas hukum atas nama Tuhan. Kedua, Islam tidak bisa disederhanakan hanya sebagai syariat, justru sebaliknya, syariat Islam adalah bagian dari Islam. Menyamakan Islam dengan syariat adalah mereduksi makna Islam itu sendiri yang sangat komprehensif. Khan menyebut 
ini adalah dampak dari tradisi intelektual Islam yang kuat dalam pendidikan hukum Islam tetapi lemah dalam filsafat politik (Muqtadir Khan dalam Al Fadl, 2004: 63). Bahkan syariat itu sendiri, sebagaian besar bukan hasil dictum Tuhan, tetapi lebih banyak hasil dari interpretasi manusia.(Al Fadl, 2004: 98)

Oleh karena itu bertolak belakang dengan yang ditulis oleh Huntington, Islam memiliki sumber daya sosial dan politik untuk mewujudkan negara demokrasi yang berhasil (Esposito, 2002). Doktrin Islam tidak menjadi penghalang bagi demokrasi (Quandt dalam Al Fadl, 2004). Nilai-nilai universal Islam yang lebih komprehensif yang mengatur persoalan sosial, ekonomi, politik, hukum dan budaya mampu menterjemahkan nilai-nilai universal demokrasi yang lebih parsial sifatnya. Para pemikir Islam moderat yang menaruh perhatian pada persoalan Islam dan demokrasi pada umumnya berkeyakinan bahwa secara normatif nilai-nilai universal demokrasi itu bukan sesuatu yang asing dalam Islam.

Meskipun di sisi yang lain juga mengakui tentang sulitnya menjelaskan secara empiris mengingat sejarah pemerintahan Islam lebih banyak didominasi oleh sistem kerajaan, kesultanan, yang bersifat militeristik, otoritarian, Perubahan kepemimpinan terjadi yang berasasl dari luar lingkaran kekuasaan maka itu berarti terjadinya perebutan kekuasan secara berdarah, yang kemudian menghasilkan dinasti baru yang tidak jauh berbeda sistem yang digunakan. Masyarakat Barat sebenarnya juga mengalami hal yang sama. Hanya saja sejak berakhirnya perang agama 30 tahun dan melemahnya dominasi Gereja Katholik yang secara langsung maupun tidak memberikan dukungan kepada penguasa-penguasa otoriter saat itu, memunculkan gagasan-gagasan tentang pembatasan kekuasaan, tanggungjawab sosial kekuasaan dan sebagainya. Ketika Barat mulai berpikir bagaimana mengurangi kekuasaan seorang pemimpin politik, dunia Islam masih dikuasai oleh kepemimpinan yang turun temurun tanpa batas waktu. Ketika kesadaran dan wabah demokrasi melanda ke negara-negara baru Islam atau mayoritas Muslim, maka muncul pula kesadaran bahwa sebenarnya demokrasi yang diperkenalkan Barat itu bukanlah sesuatu yang buruk apalagi bertentangan dengan Islam.

Nilai-nilai dalam Islam yang senafas dengan demokrasi itu dapat dilacak pada beberapa konsep antara lain, al-syura (musyawarah/consultation), Ijma atau konsensus yang mencerminkan persetujuan publik, al-musawa atau persamaan/equality, al-adalah atau keadilan (justice), al-hurriyyah atau kebebasan, alamanah atau trust dan transparan, al-salam atau perdamaian (peace) dan al-tasamuh atau toleransi. Ketujuh prinsip tersebut kesemuanya tercantum dan dapat ditemukan di dalam teks kitab suci umat Islam; al-Quran. Nilai-nilai ini justru dapat menjadi stimulan dan motor penggerak bagi demokrasi di negara-negara mayoritas Muslim. Namun demikian, rekonsiliasi Islam dan demokrasi ini bukanlah pekerjaan pendek dan sesaat, the Islamist, meskipun bisa menerima demokrasi tetapi karena tidak sepenuhnya, menjadi beban tersendiri bagi demokrasi dan Islam, seperti yang akan ditunjukkan pada bagian empirik tulisan ini. 
Selain dari perdebatan diatas, problematika relasi Islam, Islamisme dan Demokrasi juga memunculkan persoalan lain. Pertama, kontroversi pendapat yang mengatakan bahwa Islamisme adalah undemocratic. Sementara pendapat lain mengatakan bahwa Islamisme berbeda dengan Jihadisme. Islamisme, masih bersedia menerima dan mengikuti proses demokrasi, berbeda dengan Jihadisme yang memang antidemokrasi (Noah Feldman dalam Al Fadl, 2004: 95; Tibi, 2012: 95). Kedua, persoalan yang lebih mendasar, seperti yang dikatakan oleh Bayat (2005: 7), menyoal kompatabilitas Islam dan demokrasi adalah sebuah pertanyaan yang keliru. Islam adalah sebuah ajaran yang lebih kompleks daripada bisnis yang diurus oleh demokrasi, Oleh sebab itu Bayat (2005: 9) mempertanyakan:

Apakah "demokrasi" sama dengan "polyarchy" (dalam konsep) Robert Dahl pemerintahan konsensual dengan elite yang bersaing mewakili kepentingan sosial yang berbeda dalam kerangka pluralis ?. Jika ya, di mana posisi domain kehidupan publik lainnya-ekonomi, masyarakat, dan budaya? Bagaimana kita menjelaskan individualisme-sebagai prasyarat demokrasi atau antitesisnya?

Jika kita melihat pada pandangan Neo-Marx tentang adanya unequal exchange, maka kita telah menemukan inti dari permasalahan hubungan antara negara berkembang dengan PMN. Unequal exchange menunjukkan adanya ketidakseimbangan kekuatan yang dimiliki negara berkembang sehingga tidak mampu menandingi kekuatan PMN. Pemerintah negara berkembang dapat menggunakan stabilitas ekonomi dan politik untuk meningkatkan posisi tawar terhadap PMN.

Secara meyakinkan Khurshid (2000) mengatakan bahwa konsep demokrasi yang telah berkembang dalam peradaban Barat bukanlah konsep yang monolitik dan tidak bisa dipertandingkan. Dalam bahasa W.B.Gallie ia adalah essentially contested concept (Esposito \& Voll, 2003: I4). Demokrasi liberal tetap menjadi konsep yang diperebutkan (Hashemi dalam Al Fadl, 2004: 50). Demokrasi masih menjadi 'urusan yang belum selesai' dalam agenda politik modern (Anthony Arblaster dalam Khurshid, 200o). Selain sebagai konsep yang masih diperebutkan, demokrasi tetap merupakan fenomena yang berwajah banyak, baik di tingkat konseptual maupun operasional (Ahmad, 2012:15).

Oleh sebab itu Islam bisa saja mengembangkan konsep demokrasi yang berisi nilai-nilai sekuler demokrasi dan nilai-nilai sakral Islam. Ini adalah spirit seperti yang dikatakan oleh mantan Presiden Iran Khatami yang mengatakan, "Saat ini, demokrasi dunia menderita dari kekosongan besar yang merupakan kekosongan spiritualitas "dan bahwa Islam dapat memberikan kerangka kerja yang menggabungkan demokrasi dengan spiritualitas dan pemerintahan religius (Espito \& Mogahed, 2007: 56). Islam sepenuhnya mampu menampung dan mendukung demokrasi (Esposito, 2002: 159). 


\section{Kajian Empirik Relasi Islam, Islamisme dan Demokrasi di Kota Surakarta}

Tidak ada kota di Indonesia yang mengalami peningkatan jumlah dan intensitas gerakan wadah yang "memperjuangkan" Islam seperti di kota Surakarta. Organisasi keagamaan mainstream memang masih milik NU dan Muhamadiyah. Akan tetapi gemuruh gerakan pengerahan massa lebih ditampakkan oleh berbagai organisasi Islam non mainstream. Berbagai organisasi ini, baik yang tercatat maupun tidak, baik yang mempunyai massa maupun hanya pengurus saja tumbuh dengan subur. Jumlah organisasi dan gerakan ini memang cukup fantastis, meskipun perlu dikaji lebih mendalam apakah terjadi duplikasi keanggotaan dan atau kepengurusan. Di antara mereka adalah: (I) Brigade Hizbullah (2) Laskar Hizbullah (3) Laskar Sunan Bonang, (4)Laskar Zilfikar (5) Laskar Jundullah, (6) Laskar Salamah, (7) Laskar Teratai Emas, (8) Laskar Honggo Dermo, (9) Laskar Hamas, (Io) Laskar Hawariyyun, (II) Forum Umat Islam Surakarta (I2) Forum Komunikasi Aktivis Masjid (FKAM), (I3) Barisan Bismillah (I4) Front Pembela Islam (15) Front Pemuda Islam Surakarta (I6) Majelis Ta'lim al-Islah (I7) Majelis Mujahidin Indonesia (MMI), (I8) Front Pemuda Islam Surakarta, (19) Hizbut Tahrir Indonesia (20) Jamaah Islamiyah, (2I) Jamaah Ansor at Tauhid (22) Jamaah Ansor ad Daulah (23) Tim Hisbah.(24) Dewan Syariah Kota Surakarta (DSKS), (25) Front Jihad Islam (FJI), (26) Majlis Mudzakaroh.

Dengan menggunakan pendekatan psikologi, kajian ini menjelaskan tentang sikap dan penguatan identitas dalam menolak paham demokrasi liberal modern, tetapi menerima (terpaksa) sebagian praktik demokrasi tersebut. Dengan dipandu teori tentang sikap dan teori identitas, kajian ini menjawab pertanyaan mengapa para aktitivis Islam politik di Surakarta, di satu sisi mendukung sistem demokrasia liberal tetapi bersedia terlibat dalam suksesi politik yang dikelola oleh sistem demokrasi liberal tersebut? Seberapa mendalam political engagement mereka dalam proses suksesi tersebut baik di tingkat lokal, regional maupun nasional? Apakah ada kondisi tertentu atau pembatasan yang membuat keterlibatan mereka berbeda dengan masyarakat Islam lainnya yang bukan bagian dari gerakan Islamisme?

Sejauh ini, kajian tentang relasi Islam dan Demokrasi lebih menekankan pada kompatabilitas tidaknya nilai-nilai dalam demokrasi dengan ajaran Islam. Keberterimaan masyarakat Islam terhadap demokrasi atau sebaliknya penolakan mereka secara parsial dan total. Sedikit sekali atau bahkan penulis belum pernah mendapatkan kajian yang mengungkap sikap terhadap demokrasi dan perilaku berdemokrasi pada aktivis gerakan Islam yang sebenarnya menolak demokrasi tetapi bersedia mengikuti pemilihan umum meskipun dengan persyaratan yang tidak demokratis.

Kunkler \& Stepan (2013) dalam kajiannya tentang Islam dan demokrasi di Indonesia, menitikberatkan pada sikap aktor, yaitu apakah sikap aktor keagamaan merupakan kekuatan positif atau negatif bagi demokrasi? Jika positif, apakah aktor 
keagamaan tersebut berpartisipasi aktif pada semua lingkungan publik demokrasi? Apabila aktor keagamaan memandang bahwa demokrasi modern itu incompatible, dan sebuah masyarakat Islam yang baik memerlukan sistem khilafah, hukum Tuhan, bukan hukum buatan manusia, maka Kunkler dan Stepan (20I3) menawarkan untuk transisi dan konsolidasi demokrasi pada masyarakat tersebut, dibutuhkan kekuatan tokoh intelektual agama terkemuka, utamanya lagi jika mereka memimpin organisasi sosial kemasyarakatan dan aktif dalam political society yang menerima toleransi dan demokrasi (Kunkler \& Stepan, 20I3).

Dengan demikian ide-ide mreka menjadi kunci institusi demokrasi bagi pengikut mereka. Stepan (2000) mangajukan apa yang disebut dengan "twin tolerations", yaitu toleration of democracy by religion and toleration of religion by democratic leaders. Sebaliknya, Buechler (1995) mempunyai pandangan yang berbeda. Dia meragukan peran dari tokoh Islam karena menurutnya, dengan tidak adanya tokoh sentral atau terjadinya proliferasi tokoh-tokoh Islam menyebabkan lemahnya peran dan pengaruh mereka. Fragmentasi otoritas Islam dalam masyarakat sipil Indonesia membuat demokrasi menjadi berkembang tetapi di sisi lain tidak mudah mengatasi kelompok Islam yang menentang demokrasi. Alphonse F.La Porta mengakui bahwa demokrasi Indonesia memang belum sempurna dan terus terkonsolidasi.

Akan tetapi "Islamisasi (juga) merayap". Selain itu, pernyatan otkoh-tokoh politik dan agama yang diharapkan oleh Stepan tampaknya malah bertolak belakang. Misalnya Yusuf Kalla yang mengatakan "Terlalu banyak demokrasi" atau Hasyim Muzadi (alm.), yang berpendapat "Terlalu banyak pemilihan" (La Porta, 2008: 20-22). Pesimisme dan kesulitan melakukan rekonsiliasi Islam dan demokrasi lebih lanjut diungkapkan oleh Khurshid (2000), yang mengatakan bahwa demokrasi versi sekuler Barat adalah "alien" bagi prinsip, nilai dan tradisi Islam. Islam memiliki konsep demokrasi yang kaya, yang menjamin partisipasi, hukum, keadilan, dan proses konsultatif, serta respek pada hak asasi manusia. Tidak ada pertentangan antara Islam dengan demokrasi yang esensial. Kekuasaan yang despotik di negara-negara Muslim adalah "alien" karena hal itu bertentangan dengan nilai-nilai Islam. Islam dan demokrasi yang benar dapat berjalan hand in hand. Munculnya kekuasaan yang despotis, sipil maupun militrer, hasil pilihan maupun keturunan, bukanlah berasal dari ajaran Islam tapi buah dari Westernisasi dan Sekularisasi.

Secara teroritis dan empiris, jika demokrasi adalah unfinished business, maka mungkin saja relasi Islam dan demokrasi adalah the endless unfinished business. Oleh karena itu kajian ini dilakukan untuk melanjutkan urusan yang belum selesai tersebut. Bukan dengan membela Islam atau demokrasi secara sepihak. atau menawarkan solusi yang hampir mustahil, tetapi menyadari adanya gap yang tidak mudah dipertemukan akan tetapi juga tidak sampai melebar. 


\section{Islam, Islamisme dan Demokrasi dalam Perspektif Teori Sikap dan} Identitas

Para sarjana psikologi sosial telah berusaha mengurai ralasi sikap dan perilaku yang menurut mereka hubungan tersebut belum konklusif. Sebagian penelitian membuktikan adanya hubungan yang sangat kuat diantara keduanya (Fishbein \& Ajzen, 1975). Tetapi sebagian kajian menyimpulkan hubungan tersebut sangat lemah (Djalante et al., 2020; Greenwald, I980; LaPiere, 1934). Untuk menjembatani kedua pandangan ini, Warner dan DeFleur (dalam Azwar, 2013) mengajukan tiga postulat yaitu postulate of consistency, postulate of independent variation dan postulate of contingent consistency. Postulat konsistensi menjelaskan bahwa sikap verbal seseorang merupakan petunjuk akurat untuk memprediksi perilakunya. Postulat variasi independen menganggap bahwa sikap dan perilaku merupakan dua hal yang berdiri sendiri pada setiap individu, mengetahui sikap seseorang tidak berarti dapat memprediksi perilakunya. Postulat konsistensi tergantung menjelaskan bahwa hubungan sikap dan perilaku sangat ditentukan oleh faktor situasional tertentu, dimana situasi tersebut dapat mengubah hubungan sikap dan perilaku. Kondisi ketergantungan yang mengubah hubungan sikap dan perilaku tersebut antara lain, norma-norma yang hidup dan diakui dalam masyarakat, peranan individu dalam kelompok, kebudayaan dan keyakinan keagamaan.

Dalam konteks inilah maka kajian sikap dan perilaku berkembang kedalam berbagai dimensi antara lain yaitu dimensi keagamaan. Beberapa kajian yang meneliti psikologi agama dalam perspektif sikap dan perilaku seperti Agnieszka, Kanas, Scheepers, Sterkens, \& Carl (2016) yang dalam studinya antara lain menemukan fakta bahwa interreligious friendships reduce negative attitude towards the religious out-group. Sebaliknya, casual interreligious contact increases negative out-group attitudes.

Untuk memahami hubungan sikap terhadap demokrasi dan perilaku bersedia berdemokrasi kajian ini menggunakan kerangka teoritik tindakan beralasan atau theory of reasoned action dan theory of planned behavior (Fishbein \& Ajzen, 1975). Teori tindakan beralasan menjelaskan bahwa sikap terhadap perilaku bersama normanorma subjektif membentuk suatu intensitas untuk berperilaku tertentu. Sedangkan teori tindakan terencana (Casidy, Teah, Lwin, \& Cheah, 20I4: 742) pengembangan dari teori tindakan beralasan dengan menambahkan unsur perilaku yang dihayati atau perceived behavioral control.

Identitas adalah atribut laten yang melekat pada kepribadian seseorang dan atribut sosial yang dimilki atau diikuti. Dalam kajian ini, atribut laten dapat berupa perasaan dan emosi, sedangkan atribut sosial adalah keikutsertaan seseorang pada institusi sosial keagamaan tertentu. Marranci berpendapat, untuk menilai perilaku orang Islam jangan melihat pada ajaran agamanya karena yang lebih mementukan adalah identitas personalnya dan yang lebih penting lagi adalah emosi orang tersebut (Marranci, 2006: 30). Dalam mażhab sosiologi Perancis, identitas sosial terdiri dari 
identitas agama dan identitas nasional (Al Raffie, 20I3: 8I) Salah satu pendapat utama dalam teori identitas sosial adalah bahwa identitas sosial mungkin didorong oleh sistem menyeluruh makna seperti agama, tetapi juga subjek untuk dinegosiasikan sesuai dengan konteks sosial dimana hal itu diberlakukan (Al Raffie, 20I3: 8I-82). Identitas sosial agama mulai dengan, ketika kategori sosial agama terancam (Adnan, 2019: 48).

Penelitian yang bersifat deskriptif ini menggunakan data kualitatif yang didapatkan dari informasi jawaban beberapa informan kunci. Pemanfaatan dokumen sebagai data sekunder diperoleh dari beberapa sumber media online. Sejumlah informan kunci tersebut antara lain pimpinan Majlis Mudzakarah yang mempertemukan berbagai elemen organisasi dan aktivis Islam di Kota Surakarta. Dewan Syariah Kota Surakarta (DSKS), Forum Komunikasi Aktivis Masjid (FKAM). Masjlis Tafsir Al Quran (MTA) dan Lembaga Dakwah Islam Indonesia (LDII). Sedangkan informan utama adalah pengurus Cabang Nahdlatul Ulama kota

Surakarta (PCNU), Pengurus Cabang Gerakan Pemuda Ansor (PC GP Ansor), dan Pengurus Daerah Muhamadiyah (PDMD), dan Kesbangpol Jawa Tengah, serta (Eks) anggota HTI dan (eks) anggota FPI. Penggalian informasi dilakukan melalui interview, dan analisis dilakukan secara kualitatif dengan menjelaskan dan memberikan interpretasi atas data yang didapatkan baik data primer maupun data sekunder.

\section{Diskusi}

The Islamist Surakarta menganggap bahwa demokrasi itu buatan Barat dan belum tentu cocok dengan kultur bangsa Indonesia apalagi ajaran Islam. Sebagai contoh dalam pengambilan keputusan, masyarakat Indonesia sudah sejak jaman dahulu mengutamakan musyawarah, dan Islam pun mengajarkan untuk bermusyawarah. Ajaran ini dirusak oleh demokrasi yang mengajarkan pemungutan suara (voting). Pemungutan suara terbanyak juga berbahaya jika yang diputuskan itu sesuatu yang oleh syariat dilarang seperti prostitusi. Ketua FKAM Surakarta memberikan pernyataan seperti berikut:

“....demokrasi dalam arti suara terbanyak sampai pada tataran seandainya harus membuat hukum yang bertentangan dalam Islam....hukum prostitusi itu secara hukum agama apapun dilarang, namun ketika nanti dengan sistem demokrasi itu parlemen membuat aturan itu memberikan celah, itu ya sudah itu memang termasuk dalam produk demokrasi...”

Kekuatan Islam dan Islamisme di Surakarta sepakat tentang kelemahan demokrasi yang mengandalkan voting dalam pengambilan keputusan. Akan tetapi mereka berbeda pandangan dalam hal solusi yang diberikan. Bagi kelompok Islam 
(non Islamis) seperti LDII, NU dan MD, permasalahan bukan pada demokrasinya sebagai sebuah sistem tetapi pada votingnya yang dianggap tidak sesuai dengan prinsip musyawarah. Justru musyawarah itulah yang telah menyelamatkan Indonesia dari keterpecahan di awal kemerdekaan. Seandainya voting diterapkan di BPUPK dan PPKI, maka tidak hanya 7 kata yang hilang dalam Pancasila (Piagam Jakarta) akan tetapi Indonesia bisa menjadi negara agama. Namun bagi kelompok Islamis, solusi yang efektif adalah, mengganti demokrasi dengan sistem lain, yaitu khilafah. "Demokrasi kalau itu dilandasi oleh syariat Islam ya sesuai. Kalau demokrasi itu pemahamannya menyimpang dari syariat islam itu berarti tidak sesuai”.

Demokrasi memang tidak hanya persoalan pergantian kepemimpinan secara periodik, tertib, tanpa kekerasan, dan melibatkan semua unsur masyarakat. Akan tetapi juga pada persoalan pembuatan keputusan pemerintah. Sebagaimana dikatakan oleh Tansey \& Jackson (2008: I73) bahwa bagaimanapun dalam demokrasi liberal modern, demokrasi adalah persoalan kesempatan warga negara memilih pemimpinnya daripada masalah keputusan pemerintah. Secara substantif, nilai-nilai dalam demokrasi melarang adanya diskriminasi dalam proses pergantian kepemimpinan politik di semua tingkatan. Demokrasi tidak pernah dan tidak boleh membedakan mereka yang terlibat dalam proses suksesi berdasarkan perbedaan jenis kelamin, ras, suku, dan agama. Namun dalam praktiknya, ras, suku dan khususnya lagi agama, menjadi bahan pertimbangan mutlak dalam menentukan kepemimpinan politik dan publik. Bagi non Islamis, persoalan pemimpin bukan dari kalangan muslim bukanlah menjadi kendala utama dalam kehidupan plural Indonesia. Sebaliknya bagi Islamis, masalah kepemimpinan politik inilah persoalan demokrasi paling krusial yang dihadapi.

Kelompok Islam non politik, terbagi ke dalam dua pandangan tentang kepemimpinan non Islam ini. Pertama, tidak mempermasalahkan kepemimpinan non Muslim karena itu merupakan konsekuensi demokrasi. Pandangan ini diwakili oleh NU yang mengatakan:

Selama orang tersebut memang memberikan ruang yang cukup bagi umat islam untuk beribadah, memberikan ruang yang cukup untuk menjalankan syariah-syariahnya, memberikan kontribusi yang cukup bagi umat islam.... kegiatan-kegiatan keislaman kita disupport (hal itu ) sudah cukup.

Kedua, pandangan Islam non Islamis yang mengakui bahwa agama Islam bukanlah syarat bagi seorang calon pemimpin di negeri ini, seorang kepala daerah atau anggota DPRD tidaklah harus beragama Islam. Akan tetapi sebagai seorang Muslim, sudah seharusnya masyarakat Islam memilih calon-calon yang Beragama Islam karena itu adalah perintah syariat. Pandangan ini diwakili oleh MD, MTA dan LDII. Tidak hanya berharap pemimpin muslim tetapi juga menyatakan keberatan dan 
kekecewaan jika yang terpilih non Muslim. Dalam pernyataannya antara lain mereka mengatakan:

Kami selaku orang muslim, kami juga sangat mendukung dan sangat berharap yang memegang kepemimpinan itu orang muslim, kita orang muslim harus mempunyai semangat supaya yang memegang kepemimpinan itu sepaham dengan kita. Kita kan berharap dan berusaha kan begitu. Memang orang islam tidak boleh memilih orang non muslim. Tentu kami sebagai muslim ingin memiliki pemimpin yang beragama islam. Tapi ketika yang terpilih itu non muslim, ya sesuai dengan bagian negara ini tentu kami ikuti. Tidak boleh kami melawannya. Ya kami keberatan, tapi karena Undang-undangnya seperti itu ya bagimana.

Dengan demikian, Islam non politik di kota Surakarta terbagi ke dalam dua aliran yaitu yang menerima demokrasi tanpa catatan, tidak mempersoalkan kepemimpinan non Muslim di wilayah publik dan politik. Kedua Islam non politik yang bisa menerima demokrasi, juga tidak mempermasalahkan jika pemimpin non Muslim. Akan tetapi sangat berharap kepemimpinan itu dipegang seorang Muslim. "Sebagai seorang Muslim sudah seharusnya memilih yang sesama Muslim... Pemimpin itu imam, jadi seharusnya umat mengteahui siapa yang harus dipilih, tapi meski demikian ada juga saudara muslim yang memilih non Muslim".

Kelompok Islamis juga tidak bersifat tunggal, ada yang bersifat idealis, yang total menolak demokrasi seperti Hizbut Tahrir, MMI, JI dan yang lain. . Tetapi ada juga yang menerima demokrasi tetapi dalam konteks pemilihan pemimpin masih bertahan keras pada prinsip standar syariat, yaitu haram hukumnya memilih pemimpin non Muslim. Kelompok pertama termasuk dalam kategori Islamis-idealis, sedangkan yang kedua Islamis-realis. Kelompok kedua ini masih mengharapkan munculnya kekuatan demokrasi yang Islami, apakah itu bernama theo-democracy, Islamic democracy ataupun religious democracy.

Islamis-idealis bukan lagi dilemma bagi demokrasi mengingat secara prinsipiil, menolak total demokrasi, menganggapnya sebagai sistem Syaitan (toghut). Tidak hanya anti pemilihan umum, tetapi anti nation-state, dan bentuk the Islamic state adalah sebuah keharusan yang tidak bisa ditawar. Bagi kelompok ini, ide tentang misalnya NKRI bersyariah atau kembali ke piagam Jakarta bukanlah solusi untuk Islam dan umat Islam. Menerima NKRI meskipun bersyariah berarti menerima bentuk Republik dari sistem pemerintahan dan itu tidak sesuai dengan perintah untuk menegakkan sistem khilafah. Ber-NKRI berarti juga menerima konsep negara kesatuan yang berarti nasionalisme dan itu bertentangan dengan universalisme Islam. Memperjuangkan Piagam Jakarta berarti masih menerima keseluruhan lima sila yang ada dalam Pancasila. Pancasila yang diterima itu, meski terdapat Piagam Jakarta 
adalah sumber dari segala sumber hukum Indonesia. Jadi bertentangan dengan Islam yang mengajarkan Al-Quran adalah sumber segala sumber hukum. Sila kerakyatan, bertolak belakang dengan konsep kedaulatan Tuhan. Poin pentingnya adalah, menolak kepimpinan non Muslim dan sekaligus menolak terlibat dalam kegiatan sekular demokrasi dalam penentuan pemimpin meskipun Muslim.

Dalam pandangan Islamis-idealis, memilih pemimpin baik eksekutif maupun legislatif mutlak harus yang beragama Islam. Haram hukumnya dan dosa jika umat Islam memilih non muslim menjadi pemimpin mereka. Penolakan yang bersifat mutlak ini tidak hanya berlaku di daerah Surakarta, akan tetapi secara umum di level manapun. Oleh sebab itu, ketika terjadi penolakan pencalonan Basuki Cahya Purnama (Ahok) pada Pemilihan Gubernur DKI Jakarta tahun 20I7, gerakan massa yang dilakukan oleh para akvitis Islam di kota Surakarta cukup massif dan dilakukan bergelombang. Aksi tidak hanya dilakukan dengan mengikuti aksi di Jakarta tetapi juga dilakukan di kota Surakarta. Misalnya aksi ribuan umat Islam yang tergabung dalam Dewan Syariah kota Solo yang melakukan longmarch sehingga memacetkan Jl. Slamet Riyadi Solo (Sunaryo, 2016). ${ }^{3}$

Serangkaian aksi terhadap Ahok sebenarnya bukan hanya persoalan penistaan agama, karena sekalipun Ahok tidak melakukan kesalahan politik apapun, resistensi terhadap calon pemimpin non muslim tetap tinggi karena itu bagian dari penegakan syariat. Peristiwa slip lidah Ahok itu merupakan disguised accident bagi pendukung Ahok, sebaliknya menjadi blessing in disguise bagi yang anti pemimpin non Muslim. Dalam kalimat sederhana, semboyan kelompok ini adalah demokrasi yes, pemimpin non Muslim no!. Keberterimaan berdemokrasi lebih ditujukan untuk mencegah terpilihnya pemimpin yang non Muslim, ketimbang menerima demokrasi sebagai tatanan berpolitik. Dalam hal pemilihan pemimpinan politik di lembaga Legislatif, kelompok ini masih bersedia mengikuti pemilihan dengan aspirasi kepada partai yang dianggap memperjuangakan Islamisme. Menolak calon meskipun beragama Islam tetapi berasal dari partai yang dianggap tidak memperjuangkan kepentingan Islam, apalagi merugikan dan memusuhi Islam dan Islamism. Menghadapi kemungkinan pemilihan calon pejabat publik tunggal dan non Muslim, maka keyakinan mematuhi syariat lebih utama dibandingkan memeneuhi hak sebagai warga negara.

Islamis-realis, sebenarnya juga memimpikan dan menganggap sistem khilafah adalah yang terbaik karena bagaimanapun demokrasi adalah buatan manusia. Kesempurnaan hanya milik Allah dan syariat Islam adalah bentuk kesempurnaan bagi manusia. Namun demikian, demokrasi bukanlah sistem yang salah, tetapi harus diakui masih banyak sekali kekurangannya. Umat Islam wajib menegakkan kepemimpinan Islam melalui demokrasi, oleh karena itu syarat Islam untuk seorang calon pemimpin adalah wajib. Dalam hal pemimpin yang terpilih bukanlah dari golongan Islam, maka

\footnotetext{
${ }^{3}$ (www.merdeka.com>peristiwa>ribuan-umat-islam-sol....
} 
kewajiban mamatuhi syariat untuk memilih pemimpin yang Muslim sudah gugur. Hanya saja sangat disayangkan, karena dengan status mayoritas, seharusnya umat Islam memenangkan calon yang beragama Islam. Bagi kelompok ini, calon anggota Lembaga Legislatif yang beragama Islam meskipun bukan berasal dari partai yang berasaskan Islam masih layak untuk dipilih. Terlebih lagi jika keIslaman calon tersebut sangat diketahui dan terbukti membela kepentingan-kepentingan Islam. Jika dalam pencalonan pejabat publik terdapat dua calon yang semuanya beragama Islam, maka partai pengusung dan pendukung tidaklah menjadi bahan pertimbangan pilihan. Ini berbeda dengan Islamis-idealis, yang menjadikan partai pengusung sebagai referensi pilihan meskipun calon tersebut beragama Islam.

Pernyataan eksplisit dari Divisi politik DSKS membuktikan, memilih pemimpin Muslim adalah harga mati karena itu perintah syariat yang harus ditaati oleh umat Islam di manapun mereka berada. "Karena Walikota Solo tidak beragama Islam, maka kami sampai sekarang kesulitan menegakkan syariat Islam, misalnya Perda tentang larangan Miras, tentang larangan warung siobak (sate babi) dan warung guk-guk (daging anjing)."

Sikap yang sama ditunjukkan oleh ketua FKAM Surakarta yang mengatakan:

iya itu akan berlaku bagi siapapun, kalo memilih pemimpin salah satu pertimbangan agamanya apa itu secara umum juga begitu, tapi juga pasti akan melihat dari cara profesionalitasnya kan itu, karena kepemimpinan itu kan soal profesionalitas, tetapi amanah kepemimpinan itu soal tanggungjawab, nah ketika bicara tanggungjawab itu tidak terlepas dari moral, ketika sudah bicara moral, itu orang mau menggunakan timbangan moralnya itu apa, timbangan moral itu kan ada timbangan agama, nah kalo saya sebagai muslim ya akan mempertimbangkan moralnya ya agama!

Dalam menyikapi keharusan pemimpin harus Islam ini, FKAM mendasarkan argumentasi pada tuntutan amanah, yang hanya bisa diujudkan oleh pemimpin yang bermoral dan itu adalah moral agama dan moral agama adalah agama Islam. Jika tidak, maka dapat dilihat dari beberapa kebijakan Walikota yang mempersulit beberapa Perda syariat. Menurut FKAM, kalaupun walikota Solo (Surakarata) yang bukan Muslim itu tidak merugikan umat Islam, iya karena dia terpilih di periode kedua juga karena dukungan umat Islam. Tetapi kalau dikatakan dia memperjuangkan kepentingan Islam, sudah pasti tidak, karena dia paling hanya memberikan persetujuan. Walikota bahkan pernah melarang kegiatan halal bihalal di balaikota, tetapi setelah diprotes umat Islam akhirnya diperbolehkan lagi.

Mempertemukan sikap dan pandangan dari Islam (non politik) dan Islamisme tidaklah mudah, apalagi mempertemukan Islam dan demokrasi, terutama Islamismeidealis. Sikap negatif yang sangat kuat ini sebagian bukan karena nilai-nilai inheren dalam demokrasi khususnya tentang suksesi. Suksesi yang rutin, teratur, tanpa 
kekerasan, berkeadilan adalah sesuatu yang diakui positif. Akan tetapi karena konsep tersebut berasal dari Barat dan Barat adalah musuh Islam, Barat adalah Kristen, kolonialis-imperialis dan hegemonik maka konsep tersebut tidak perlu dicari kompatabilitasnya dengan ajaran Islam. Perlawanan terhadap Barat adalah bagian dari pembentukan identis Muslim yang syar'i, Dengan demikian, persoalan ketegangan hubungan antara Islam dan demokrasi di Surakarta, sebenarnya imbas atau bagian kecil dari pertarungan besar yang terjadi di tingkat global, yaitu ideologi besar Islam dan Kristen atau Timur dan Barat. The Islamist dan utamanya lagi Jihadis yang anti Barat berhadapan dengan Barat yang anti Islam atau yang mengidap Islamphobia. Pernyataan Presiden Bush pada 20 September 200I di hadapan Konggres, "Every nation, in every region, now has a decision to make. Either you are with us, or you are with the terrorists." (Voanews.com, 2009). Kalimat ini tidak memberikan alternatif dan hanya menyisakan dua pilihan sehingga semakin tidak produktif untuk memasarkan ide-ide demokrasi Barat.

Dengan mengadopsi pendapat Freud (1856-1939) tentang ego defense mechanism, maka ada self defense mechanism sehingga tidaklah mudah untuk mengubah sikap yang sudah melekat pada Islammis yang berusaha untuk mengembangkan mekanisme mempertahankan diri, terlebih lagi jika yang dipertahankan itu sebuah nilai yang sakral. Sikap ideologis Islamis akan selalu dimanifestasikan ke dalam perilaku untuk memperlihatkan identitas ke Islam an mereka vis a vis Barat yang demokrasi.

Pertentangan ideologi besar dengan masing-masing pendukung tampaknya masih akan berlangsung lama(Huntington \& Simamora, 1983) dan pengikutnya dengan tesis anti Islamnya yang sangat kuat aromanya (Huntington \& Simamora, 1983). Taqiyyuddin al Nabhani dengan ide khilafahnya yang tidak mudah menyerah, Sayid Qutub yang mengidamkan kejayaan Kembali Islam melalui sistem khilafah Islamiyyah (Al Nabhani, 2002; Sayyid Khatab,200), dan tidak ketinggalan Hasan al Banna dan Al Maududi (1990) yang menginspirasi gerakan Islam politik di Mesir dan banyak negara Islam. Mereka menghadapi dilema antara fakta politik kekalahan Islam politik dan idealisme merebut kembali kejayaan Islam dengan menolak total demokrasi atau keterpaksaan mengadopsi sebagian nilai-nilai sekular demokrasi. Di sisi lain, Ikhtiar intelektual untuk mencari solusi atau setidaknya rekonsiliasi kedua nilai tersebut tidaklah berhenti, seperti usaha tanpa mengenal lelah yang dilakukan oleh Esposito \& Voll (2003), Bayat (2007), dan Al Fadl (2004).

Ketika usaha untuk mengurangi tekanan Islamisme yang ditawarkan oleh Esposito melalui kekuatan intelektual tokoh-tokoh Islam yang aktif di institusi politik dan masyarakat sipil tidak mudah dilakukan, maka mempersempit gap Islamisme dan demokrasi melalui pendidikan formal dan non formal masih dapat dilakukan, dengan harapan dapat memperkecil jumlah pengikut paham Islamisme atau Islam politik, fundamentalisme dan utamanya Jihadis. 


\section{Penutup}

Demokrasi politik di kota Surakarta, untuk waktu yang sulit diprediksi hingga kapan, akan senantiasa diwarnai dan dibayang-bayangi standar syariat Islam dalam menentukan kepemimpinan politik di daerah. Warna dan bayang-bayang ini disebabkan oleh sikap politik aktivis Islam dan terlebih lagi Islam politik. Gerakan aktivis Islam di luar NU, seperti MD, MTA, dan LDII meskipun tidak mengharamkan pemimpin non-Muslim, akan tetapi keinginan kuat untuk mendapatkan pemimpin Muslim merupakan agenda dakwah politik.

Gerakan Islam politik-idealis, meskipun tidak bersedia terlibat dalam proses suksesi, akan tetapi penolakan mereka terhadap demokrasi turut mewarnai demokrasi politik di Surakarta. Implikasi dari gerakan ini bisa negatif dan menjadi duri bagi demokrasi di Surakarta.

Gerakan Islam politik-realis, menerima demokrasi sebagai sistem yang sah, akan tetapi mengharamkan pemimpin non-muslim. Pengharaman ini mendorong mereka untuk mempertimbangkan sistem alternatif seperti yang ditawarkan oleh Islam politik idealis; yaitu sistem khilafah.

Keterlibatan politik Islam dan dan Islam politik dalam proses demokrasi di Surakarta cukup tinggi, karena dilandasai oleh kepentingan syar'i (syariat sesuai dengan interpretasi masing-masing) untuk memilih pemimpin yang Islam dan Islami.

Sikap politik aktivis Islam dan Islamis mengkristal dalam sebuah tindakan sebagai ekpresi untuk memperlihatkan identitas keIslaman mereka dalam praktik demokrasi liberal modern di Surakarta, yang bisa saja dipahami sebagai sebuah perlawanan tersembunyi atau soft resistance terhadap sistem yang berlaku.

\section{Ucapan Terima Kasih}

Terimakasih kepada kolega penulis di Departemen Politik dan Pemerintahan, Universitas Diponegoro yang telah berbagi diskusi dan catatan kritisnya sehinga artikel ini bisa dibaca seperti saat ini.

\section{Pendanaan}

Penulis tidak menerima bantuan pembiayaan atau dana untuk penelitian, kepenulisan (authorship), dan publikasi dari pihak manapun

\section{Daftar Pustaka}

Adnan, M. (20I9). Konflik Keagamaan: Studi Kasus pada Politik Dakwah MTA dan Implikasi Sosialnya. Universitas Diponegoro.

Agnieszka, Kanas, Scheepers, Sterkens, P., \& Carl. (20I6). Religious Identification and Interreligious Contact in Indonesia and the Philippines: Testing the Mediating 
Roles of Perceived Group Threat and Social Dominance Orientation and the Moderating Role of Context. European Journal of Social Psychology, 46(6), 700-715. Akbar, A. (2016). The Political Discourses of three Contemporary Muslim Scholars: Secular, Nonsecular, or Pseudosecular? Digest of Middle East Studies, 25(2), 393-408. Al Fadl, K. A. (2004). Islam and the Challenge of Democracy. Princeton University Press. Al Raffie, D. (20I3). Social Identity Theory for Investigating Islamic Extremism in the Diaspora. Journal of Strateg i Security, 6(4), 67-9I.

An-Naim, A. A. (2008). Islam and the Secular State: Negotiating the Future of Sharia. Harvard University Press.

Azwar, S. (2013). Sikap Manusia dan Pengukurannya. Yogyakarta: Pusat Belajar Offset. Bayat, A. (2005). Islamism and Social Movement Theory. Third World Quarterly, 26(6), 89I-908.

Bayat, A. (2007). Islam and Democracy: What is the Real Question? Amsterdam: Amsterdam University Press.

Buechler, S. M. (1995). New Social Movement Theories. Sociological Quarterly, 36(3), 44I464 .

Casidy, R., Teah, M., Lwin, M., \& Cheah, I. (2014). Moderating Role of Religious Beliefs on Attitudes Towards Carities and Motivation to Donat. Asia Pacific Journal of Marketing and Logistics.

Djalante, R., Lassa, J., Setiamarga, D., Sudjatma, A., Indrawan, M., Haryanto, B., ... Rafliana, I. (2020). Review and Analysis of Current Responses to Covid-I9 in Indonesia: Period of January to March 2020. Progress in Disaster Science, 6, I0009I.

Esposito, J. L. (2002). What Everyone Needs to Know About Islam. Oxford: Oxford University Press.

Esposito, J. L., \& Mogahed. (2007). Who Speaks for Islam? Gallup Press.

Esposito, J. L., \& Voll, J. O. (2003). Islam and the West. Religion in International Relations. Palgarave Macmillan, New York.

Fishbein, M., \& Ajzen, I. (1975). Belief, attitude, intention, and behavior: an introduction to theory and research. Massachusetts: Addison-Wesley Pub. Co.

Fukuyama, F. (2006). The end of history and the last man. Simon and Schuster.

Greenwald, A. G. (1980). The totalitarian Ego: Fabrication and Revision of Personal History. American Pshycologist, 35(5), 603.

Hefner, R. W. (2012). Islamic Radicalism in Democratizing Indonesia. In S. Akbarzadeh (Ed.), Routledge Handbook of Political Islam. Abingdon: Routledge.

Huntington, S. P., \& Simamora, S. (1983). Tertib Politik di dalam Masyarakat yang sedang Berubah. CV. Rajawali.

Karabela, M., \& Brenna, D. (2015). A Distinctive Form of Muslem Politics. Reviews, 4(5). Khurshid, A. (2000). Islam and Democracy: Some Conceptual and Contemporary Dimensions. The Muslim World, 9o(I/2), I.

Kunkler, M., \& Stepan, A. (2013). Democracy and Islam in Indonesia. Journal of Democracy, II(4), 37-57. 
Kuru, T. A. (2009). Secularism and State Policies toward Religion: The United States, France, and Turkey. Cambridge University Press.

La Porta, A. F. La. (2008). Islam and Democracy in Indonesia. Junaita Voices, I9(22).

LaPiere, R. T. (1934). Attitudes VS Actions. Social Forces, I3(2), 230-237.

Marranci, G. (2006). Jihad Beyond Islam. Oxford: UK-New York: Berg.

Maududi, A. al A. (1990). Khilafah dan Kerajaan. Jakarta: Penerbit Kharisma.

McClay, W. M. (2002). Two Concepts of Secularism . Baltimore. In In Religion Returns to the Public Square: Faith and Policy in America (Hugh Heclo). MD: The Johns Hopkins University Press.

Potrafke, N. (2012). Islam and democracy. Public Choice, I5I(I/2), I85-I92.

Rowley, C. K., \& Smith, N. (2009). Islam's democracy paradox: Muslims Claim to Like Democracy, So Why do they Have so Little? Public Choice, 139(3), 273-299.

Schneier, E. (2015). Muslim Democracy: Politics, Religion and Society in Indonesia, Turkey and the Islamic world. Routledge.

Sunaryo, A. (20I6). Ribuan Umat Islam Solo Kecam Pembantaian di Aleppo. Retrieved from https://www.merdeka.com/peristiwa/ribuan-umat-islam-solo-kecampembantaian-di-aleppo.html

Stepan, Alfred. 200o. "Religion, Democracy, and the "Twin Tolerations"." Journal of Democracy II (4):37-57.

Tansey, S., \& Jackson, N. (2008). Politics: The Basics, Routledge 270 Madison Ave. New York: NY Iooi6.

Tibi, B. (2012). Islamism and Islam. Yale University Press.

Todorov, T. (2004). The Inner Enemies of Democracy. Inggris: Polity Press.

Voanews.com. (2009). You Are Either With Us, Or With the Terrorists.

\section{Tentang Penulis}

Muhammad Adnan adalah dosen Ilmu Pemerintahan, Departemen Politik dan Pemerintahan, Fisip, Universitas Diponegoro. Penulis memiliki area riset seputar politik dan agama, perbandingan politik, dan menejemen networking. 